\title{
Potentially misleading GPS-levelling-based assessment of gravimetric quasi/geoid models due to vertical land motion and different GPS processing software
}

\author{
W.E. Featherstone \\ School of Earth and Planetary Sciences, Curtin University of Technology, GPO Box U1987, Perth, WA 6845, Australia \\ ORCID: http://orcid.org/0000-0001-9644-4535 \\ Email: W.Featherstone@curtin.edu.au
}

\section{T.J. Lyon}

School of Earth and Planetary Sciences, Curtin University of Technology, GPO Box U1987, Perth, WA 6845, Australia ORCID: https://orcid.org/0000-0002-4838-5857

Email: Todd.Lyon@curtin.edu.au

\section{J.C. McCubbine}

National Geodesy Section, Geoscience Australia, GPO Box 378, Canberra, ACT 2601, Australia

ORCID: http://orcid.org/0000-0002-6939-1340

Email: Jack.McCubbine@ga.gov.au

\begin{abstract}
Gravimetric geoid or quasigeoid models are often evaluated using Global Positioning System (GPS) and levelling, but the veracity of these "control" data is not always considered. Using a precisely surveyed 40$\mathrm{km}$-long traverse of 62 points in Perth, Western Australia, we exemplify that vertical land motion and the choice of GPS processing software may lead to spurious conclusions as to which is the "best" model, particularly with regards to the assessment in the presence of tilts among these datasets. We recommend that the effect of vertical land motion (if present) is factored into such evaluations, GPS data are processed using the same software and in the same reference frame, and tilts among the datasets are considered during the evaluations.
\end{abstract}

Key words: quasigeoid evaluation, vertical land motion, GPS-levelling

\section{Introduction}

This investigation is motivated - in part - by an incompletely explained tilt of $\sim 1 \mathrm{~mm} / \mathrm{km}$ among gravimetric quasigeoid models and digital astrogeodetic vertical deflections collected along a $\sim 40-\mathrm{km}$-long traverse in Perth, Western Australia (Schack et al., 2018). Prime candidates were the proximity to the coast, where altimeter-derived and ship-track gravity anomalies are poor (e.g., Vignudelli et al., 2011; Featherstone, 2009), and the large mass-density contrast at the near-vertical Darling Fault that generates a very steep gravity gradient (e.g., Middleton et al., 1993). However, another candidate explanation for the tilt could be land subsidence in the Perth Basin (Featherstone et al., 2015; Parker et al., 2017a; Lyon et al., 2018), which will be investigated here. We will also investigate the use of different GPS processing software, as different packages can give different results.

The digital astrogeodetic traverse was co-located with a repeat levelling traverse that has been used to quantify vertical land motion (VLM) associated with groundwater abstraction from the Perth Basin. The land is subsiding at approximately $3 \mathrm{~mm} / \mathrm{yr}$, with a superposed seasonal signal of a few millimetres (Lyon et al., 2018). This is compounded by non-linear subsidence when groundwater abstraction rates change (Featherstone et al., 2015) and localised larger rates of subsidence associated with wetlands (Parker et al., 2017a). Since the establishment of the Australian Height Datum (AHD; Roelse et al., 1971, 1975), Lyon et al. (2018, Figure 10) estimate subsidence in the Perth Basin to be a total of $\sim 90 \mathrm{~mm}$ until Sept 2017.

We have conducted numerous previous studies in the Perth region relating to: (i) heights and height systems (Friedlieb et al., 1997; Allister and Featherstone, 2001); (ii) temporal changes in heights (Featherstone et al., 2015; Parker et al., 2017a, 2017b; Lyon et al., 2018); and (iii) quasi/geoid modelling by 
various techniques (Featherstone, 2000; Claessens et al., 2001; Darbeheshti and Featherstone, 2010). In the present study, we use reasonably long occupation ( 6 hours) dual-frequency carrier-phase Global Positioning System (GPS) data along our precisely surveyed repeat levelling traverse to investigate whether the $\sim 1 \mathrm{~mm} / \mathrm{km}$ tilt between gravimetric quasigeoid models and astrogeodetic vertical deflections reported by Schack et al. (2018) could be explained by this additional candidate. We also investigate the effect of $\sim 90 \mathrm{~mm}$ of land subsidence over $\sim 40$ years on gravimetric quasigeoid computation, finding it to be insignificant in this case.

\section{Reference frames}

Different reference frames are involved when assessing gravimetric quasi/geoid models with GPS-levelling:

- The reference frame used in the processing of GPS data is largely uncontroversial, so long as it is chosen to be consistent with that used in the gravimetric quasi/geoid model (but see below). However, different post-processing packages can deliver different results as will be shown later.

- The reference frame used in gravimetric quasi/geoid models is somewhat nebulous (cf. Pavlis, 1988; Kotsakis, 2008, 2009). Satellite-only models have an implicit reference frame from the ground tracking stations used to compute orbits before inversion for the gravity field coefficients. Combined satelliteterrestrial and regional models also require the regional terrestrial gravity anomalies to have been transformed to a geocentric frame (cf. Featherstone, 1995), but this is not always documented.

- The reference frame (vertical datum) used for the levelling is even more nebulous. 1) The height system used (e.g., normal, Helmert orthometric, normal-orthometric, etc.) must be consistent with the gravimetric quasi/geoid model to be tested (e.g., Featherstone and Kuhn, 2016). 2) Vertical datums are not unified globally, and each is offset due principally to the effect of the ocean's time-mean dynamic topography on the tide gauges used to observe local mean sea level (e.g., Filmer et al., 2018 and the references cited therein). 3) If more than one tide gauge is fixed to realise a local vertical datum, then tilts and distortions may be introduced, as is the case for the AHD (Featherstone and Filmer, 2011). In the Perth region, the use of so-called "metropolitan and buffer zones" exempted levelled heights in the metropolitan region from the AHD in order to avoid discrepancies with the previously established tidal vertical datum at Fremantle (Roelse et al., 1971, 1975). The difference in heights is $40 \mathrm{~mm}$ for the "metropolitan zone", but which entirely covers our repeat levelling profile.

- Tide systems also affect all of the GPS, levelling and quasigeoid datasets used in these assessments (e.g., Ekman, 1989; Vatrt, 1999), but this effect will not be discussed further here because of the short $(\sim 40 \mathrm{~km})$ length of the EW profile. In particular, the conversions among tide systems (tide-free, zerotide, mean-tide) are all functions of latitude, so do not affect an EW profile, but should be considered for non-EW profiles.

Reference frames also come into play during the synthesis of quasi/geoid heights from spherical harmonic coefficients, where the zero-degree term and scaling for the use of different reference ellipsoids need to be applied so as to be consistent with the reference ellipsoid used for the GPS processing (cf. Smith, 1998). For instance, the zero-degree term for the Earth Gravitational Model EGM2008 (Pavlis et al., 2012, 2013) is $0.410 \mathrm{~m}$ for the GRS80 reference ellipsoid, which is the ellipsoid also used in this study.

Descriptive statistics (maximum, minimum, mean, standard deviation) are commonly used to summarise the evaluation of gravimetric quasi/geoid models with GPS-levelling. While the maximum, minimum and mean can be useful for the detection of outliers, the more informative statistic is the standard deviation (STD). This is because the zero-degree term is not well determined and the vertical datum can be offset from the geoid, rendering the maximum, minimum and mean less informative, likewise for the root mean square (RMS). However, if there is a tilt among the datasets, the sole use of descriptive statistics to assess quasi/geoid models can be violated because the residuals may not follow a Gaussian (normal) distribution. As such, we also compute STD after removal of a tilt to gauge this potentially misleading effect, albeit over a short ( $\sim 40 \mathrm{~km})$ profile. 


\section{Vertical land motion (VLM)}

Land subsidence or uplift has multiple and compounding effects on the assessment of gravimetric quasi/geoid models with GPS-levelling. Ideally, all observations should refer to the same time-epoch, but this is usually unrealistic, as follows:

- GPS observations processed in any realisation of the International Terrestrial Reference Frame (ITRF) usually refer to the mean epoch of those observations. As such, the ellipsoidal height will represent the averaged ground height at that time, so is not necessarily compatible with data observed at different times, especially in the presence of VLM.

- The epoch of levelling observations is nebulous. Differential levelling for nation-wide vertical datum realisation is a time-consuming procedure and is typically conducted with different traverses over many years (e.g., Lines, 1992, Chapter 5; Zilkoski et al., 1992). Some approaches to specify the epoch of the levelling data could be to assign: (i) it as the date of the least squares adjustment of the vertical datum (e.g., 1971 in the case of the AHD); (ii) a mean epoch of the levelling observations in a localised area (cf. Lyon et al., 2018, Section 4.1); or (iii) levelling observations extrapolated to the mean epoch of the GPS observations using estimates of the VLM. These three permutations will be considered later.

- The epoch of the quasi/geoid computation is even more nebulous in the presence of VLM. With the exception of Gravity Recovery and Climate Experiment (GRACE) satellite-only models, their epoch is an amalgamation of the times of all the various data employed therein. Land gravity surveys, for instance, are conducted in different areas at different times due to the time-consuming nature of these observations (much like levelling).

With regards to this last point, we ran a very simple experiment in the Perth region to loosely quantify the effect of land subsidence on quasigeoid computations. This has to be qualified with the following gross assumptions and simplifications: 1 ) The change in gravity is taken to be due to VLM only (using the linear free-air gradient of $+0.3086 \mathrm{mGal} / \mathrm{m}$, Bouguer plate gradient of $-0.1119 \mathrm{mGal} / \mathrm{m}$ ) and $\sim 80 \mathrm{~mm}$ subsidence since $\sim 1975$, thus neglecting subsurface mass changes and redistributions from the cause(s) of the subsidence. 2) All land gravity observations in the Perth region were made in 1975 so will have been subjected to the same subsidence. 3) The land subsidence is a constant $\sim 80 \mathrm{~mm}$ in a NS band that is bound by the $116^{\circ} \mathrm{E}$ meridian (approximating the Darling Fault which separates the Perth Basin from the assumedstable Yilgarn Craton) and the coastline defined by GMT (Wessel and Smith 1996; Wessel et al., 2013).

The 1'x1' gravity anomaly grid elements used in the AGQG2017 model (Featherstone et al., 2018) were thus increased by $+0.016 \mathrm{mGal}$ in this band. Following the same computational procedures and parameters used by Featherstone et al. (2018), the land-subsidence effect on the computed quasigeoid is very small, increasing by at most $0.3 \mathrm{~mm}$. As such, this is not investigated further, but should be considered in other regions that exhibit larger amounts of VLM and over longer periods of time.

\section{Results and Discussions}

\section{Different levelling surveys}

We have a variety of differentially levelled height data in the Perth Basin, comprising: (a) the "official" AHD heights published by Landgate (though not strictly AHD because of the "metropolitan and buffer zones"; Roelse et al., 1971, 1975); (b) a least squares adjustment of digitised historical levelling around the repeatlevelled traverse from Lyon et al. (2018, Section 4.1); (c) a repeated first-order levelling traverse, with the latest survey conducted in September 2017 (Lyon et al., 2018). Lyon et al. (2018) also estimated linear and seasonal terms for the VLM in the Perth Basin, which are used here to predict levelled heights to the epochs of the GPS observations ( $d$ and e). The levelling data used in (b) and (c) have been fixed to the assumed-stable benchmark F369A on the Yilgarn Craton $(H=111.499 \mathrm{~m})$, but recall that the mean value of the GPS-levelling discrepancies will not be assessed.

We first assess seven reasonably recent gravimetric quasigeoid models (Table 1 ) using these different levelling data (options a through e). EGM2008 was synthesised to degree 2190 and order 2159 directly at each GPS-levelling point, whereas GGMplus and all Australian quasigeoid models were bi-cubically interpolated from their respective grids. AUSGeoid98 includes a 'patch' that was applied in the Perth region where it was fitted to GPS-levelling (Featherstone, 2000). GGMplus and all Australian quasigeoid models are based on the full expansion of EGM2008. The 'hybrid' AUSGeoid09 and 'hybrid' AUSGeoid2020 
models have been fitted to nation-wide GPS-AHD heights using least squares prediction (cf. Featherstone and Sproule, 2006). GGMplus (Hirt et al., 2013) does not include gravity data additional to that used in EGM2008, instead using Newtonian forward modelling of the gravity field from a residual terrain model.

\begin{tabular}{|c|c|c|c|c|c|c|c|}
\hline & EGM2008 & GGMplus & AUSGeoid98 & AGQG2009 & AUSGeoid09 & AGQG2017 & $\begin{array}{c}\text { AUSGeoid } \\
2020 \\
\end{array}$ \\
\hline Citations & $\begin{array}{l}\text { Pavlis et al. } \\
(2012,2013)\end{array}$ & $\begin{array}{l}\text { Hirt et al. } \\
(2013)\end{array}$ & $\begin{array}{l}\text { Featherstone et al. } \\
\qquad \begin{array}{l}(2001) ; \\
\text { Featherstone } \\
(2000)\end{array}\end{array}$ & $\begin{array}{l}\text { Featherstone } \\
\text { et al. (2011) }\end{array}$ & $\begin{array}{l}\text { Brown et al. } \\
\qquad(2011)\end{array}$ & $\begin{array}{l}\text { Featherstone } \\
\text { et al (2018) }\end{array}$ & $\begin{array}{l}\text { Brown et } \\
\text { al. }(2018)\end{array}$ \\
\hline $\begin{array}{l}\text { Spatial } \\
\text { resolution }\end{array}$ & $5^{\prime} \times 5^{\prime}$ & $1^{\prime} \times 1^{\prime}$ & $2^{\prime} \times 2^{\prime}$ & $1^{\prime} \times 1^{\prime}$ & $1^{\prime} \times 1^{\prime}$ & $1^{\prime} \times 1^{\prime}$ & $1^{\prime} \times 1^{\prime}$ \\
\hline $\begin{array}{l}\text { Fitted to } \\
\text { GPS-AHD }\end{array}$ & No & No & Perth only & No & Yes & No & Yes \\
\hline $\begin{array}{l}\text { Land gravity } \\
\text { data }\end{array}$ & $\begin{array}{c}\text { NGA holdings } \\
\text { sourced from } \\
\text { GA } \\
\end{array}$ & N/A & $\begin{array}{c}\text { GA (holdings as at } \\
\text { Jan 1980) }\end{array}$ & $\begin{array}{l}\text { GA (holdings } \\
\text { as at July } \\
2009)\end{array}$ & -- & $\begin{array}{l}\text { GA (holdings } \\
\text { as at May } \\
\text { 2016) } \\
\end{array}$ & -- \\
\hline $\begin{array}{l}\text { Altimeter- } \\
\text { derived } \\
\text { gravity data }\end{array}$ & DNSC07 & N/A & $\begin{array}{l}\text { (Sandwell and } \\
\text { Smith, 1997) v18 }\end{array}$ & $\begin{array}{c}\text { DNSC08GRA } \\
\text { (Andersen et } \\
\text { al., 2010) }\end{array}$ & -- & $\begin{array}{l}\text { Sandwell et al. } \\
\text { (2014) v23.1 }\end{array}$ & -- \\
\hline $\begin{array}{l}\text { Digital } \\
\text { elevation } \\
\text { model } \\
\text { (DEM) }\end{array}$ & $\begin{array}{c}\text { DTM2002 } \\
\text { (Saleh and } \\
\text { Pavlis, 2003) }\end{array}$ & $\begin{array}{l}\text { SRTM v4 } \\
\text { (Farr et } \\
\text { al., 2007) } \\
\text { and } \\
\text { DTM2002 }\end{array}$ & $\begin{array}{l}\text { 9"x9" GEODATA- } \\
\text { DEM9S v1, but } \\
\text { generalised to } \\
27 " \times 27 " \text { (cf. Kirby } \\
\text { and Featherstone) }\end{array}$ & $\begin{array}{c}9 " \times 9 " \\
\text { GEODATA- } \\
\text { DEM9S v3 }\end{array}$ & -- & $\begin{array}{l}\text { 1"x1" DEM-H } \\
\text { (Gallant et al., } \\
\text { 2011) }\end{array}$ & -- \\
\hline
\end{tabular}

Table 1: Summary of quasigeoid models evaluated in this study, including source data for the gravimetric-only models

With regard to the GPS reference frame to use with the Australian quasigeoid models, AUSGeoid98 and AUSGeoid09 have to be used with GDA94 ellipsoidal heights and AUSGeoid2020 has to be used with GDA2020 ellipsoidal heights. This is because these reference frames were used in the fitting to GPS-AHD data (Brown et al., 2011, 2018; Featherstone, 2000), so no other frames will be used in their assessment below. However, different frames will be used here to assess the gravimetric-only models.

Our first set of results is presented to determine the effect of VLM on the evaluation of quasigeoid models. The first subset is a comparison with what we term 'pre-subsidence' levelled heights, comprising the published "metropolitan zone" AHD heights of the benchmarks, as well as the localised adjustment of historical levelling data from Lyon et al. (2018, Section 4.1). The second subset is what we term 'postsubsidence' levelled heights from Lyon et al. (2018), comprising the September 2017 first-order levelling survey, and extrapolation to the epochs of the GPS observations using the linear trend only and the linear plus seasonal terms. We acknowledge that caution should be exercised in employing the seasonal terms from Lyon et al. (2018) because they are poorly determined from only two repeat levelling surveys per annum over a 3.5-year period.

Figure 1 and Table 2 show that the land subsidence has made a significant difference to the evaluation of the quasigeoid models using GPS-levelling. The 'pre-subsidence' levelling (cases a and b) exhibit larger tilts than the 'post-subsidence' levelling (cases $c$, $d$ and e), including a change of sign in some cases. The quasigeoid models that have been fitted to the "official" AHD give better agreements with the "presubsidence' levelling, but not so with the 'post-subsidence' levelling. This is to be expected given that the fitting was to AHD values and not to the new 'post-subsidence' levelling. 

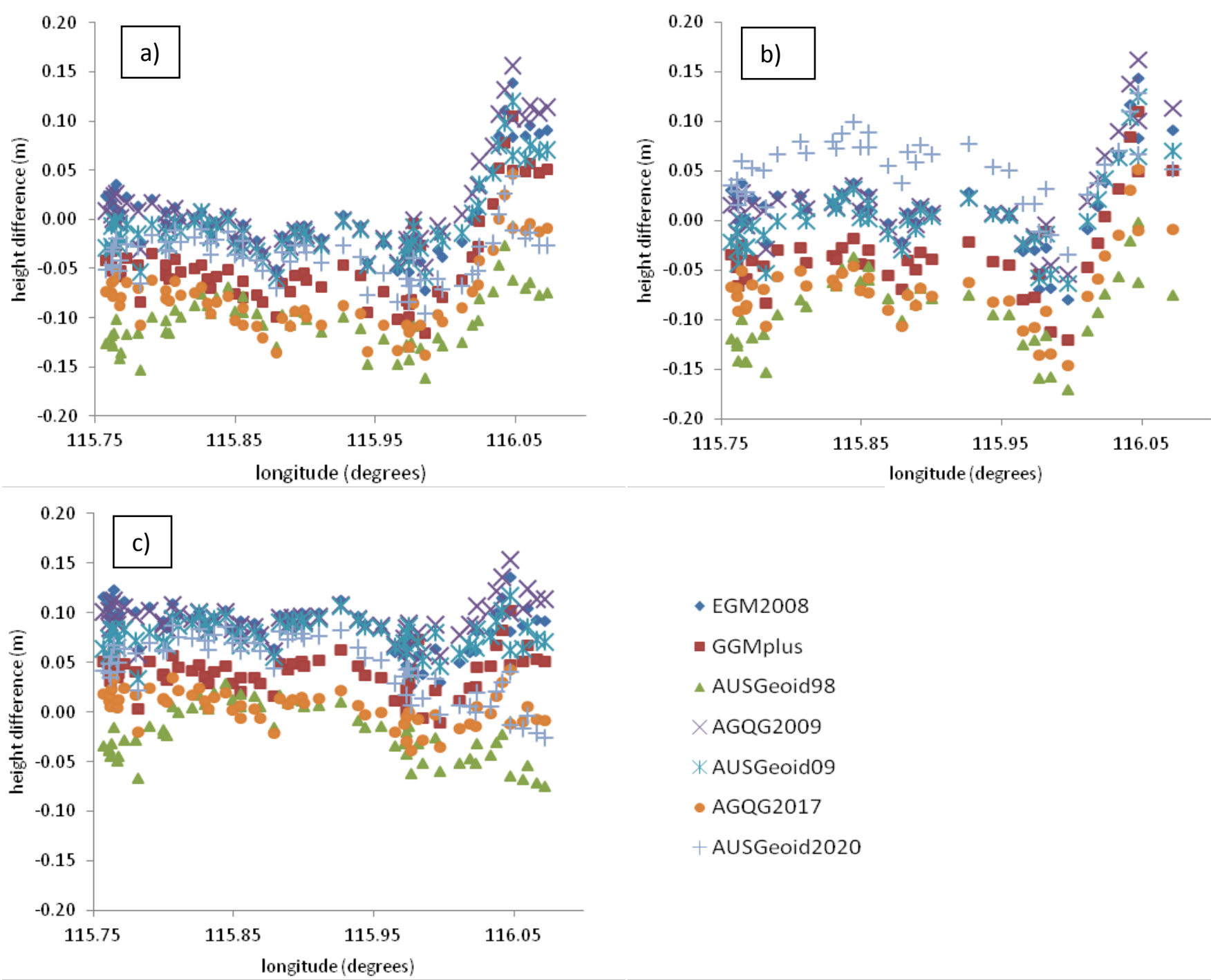

- EGM2008

- GGMplus

$\triangle$ AUSGeoid98

$\times$ AGQG2009

* AUSGeoid09

- AGQG2017

+ AUSGeoid2020
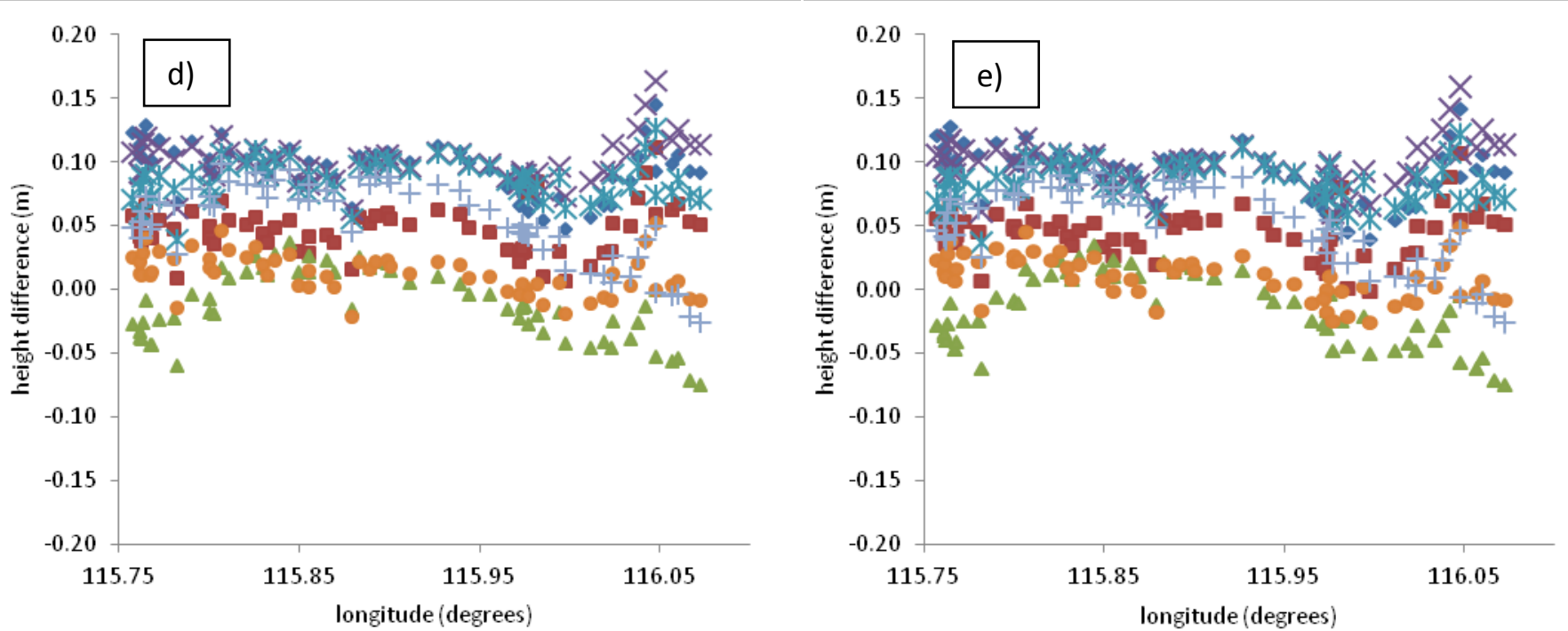

Figure 1: Differences between GPS-levelling and quasigeoid models (metres) for different levelling surveys versus longitude (degrees): a) "official" published AHD71 heights; b) the localised historical levelling adjustment from Lyon et al. (2018, Section 4.1); c) first-order levelling in Sept 2017; and Sept 2017 levelling projected to the epoch of GPS observations using a linear VLM term (d) and linear plus seasonal VLM terms (e).

In terms of choosing the "best" quasigeoid model from the STD in Table 2, the removal of the tilt can lead to different inferences. For instance, using the STD before the removal of the tilt and the 'postsubsidence' levelling would indicate that AUSGeoid09 is superior to AGQG2017, but after removal of the tilt would indicate vice versa. Admittedly, removal of tilts over this $40-\mathrm{km}$-long traverse only has a small effect on the standard deviations, but this effect could be larger for vertical datums with a larger tilt and 
https://ascelibrary.org/doi/10.1061/\%28ASCE\%29SU.1943-5428.0000293

over longer distances (e.g., Penna et al., 2013). The AHD contains a north-south tilt of $\sim 1 \mathrm{~m}$ over $300 \mathrm{~km}$ (Featherstone and Filmer, 2012), so Featherstone et al. (2018, Figure 5) show plots versus GPS-AHD with and without removal of a tilted plane. The STD is approximately $50-90 \mathrm{~mm}$ lower when a tilted plane is removed from the quasigeoid-GPS-levelling residuals.

The tilts in Table 2 for many of the quasigeoid models are commensurate with or even larger than the $\sim 1 \mathrm{~mm} / \mathrm{km}$ reported by Schack et al. (2018) when using independent measurements of vertical deflections. Most notably, the tilt for the AHD data in Table 2 (items a and b) for AGQG2017 (also used by Schack et al. (2018)) is $\sim 1 \mathrm{~mm} / \mathrm{km}$. As such, their attribution of the tilt in the quasigeoid coming from the poorer coastal altimeter data and steep gravity gradient (see the introduction to this article) becomes more conclusive when also considering the GPS-levelling data.

\begin{tabular}{|c|c|c|c|c|c|c|c|c|}
\hline & & EGM2008 & GGMplus & AUSGeoid98 & AGQG2009 & AUSGeoid09 & AGQG2017 & AUSGeoid2020 \\
\hline & $\begin{array}{l}\text { Fitted to } \\
\text { GPS-AHD }\end{array}$ & No & No & Perth only & No & Yes & No & Yes \\
\hline & GPS frame & GDA94 & GDA94 & GDA94 & GDA94 & GDA94 & GDA2020 & GDA2020 \\
\hline \multirow{4}{*}{$\begin{array}{r}(a) \\
\text { "official" } \\
\text { AHD } \\
1971\end{array}$} & STD (mm) & \pm 44 & \pm 47 & \pm 29 & \pm 48 & \pm 38 & \pm 39 & \pm 25 \\
\hline & $\begin{array}{l}\text { Linear tilt } \\
(\mathrm{mm} / \mathrm{km})\end{array}$ & $1.0 \pm 0.5$ & $1.9 \pm 0.5$ & $0.9 \pm 0.3$ & $2.0 \pm 0.5$ & $2.0 \pm 0.4$ & $1.1 \pm 0.4$ & $0.0 \pm 0.3$ \\
\hline & $\mathrm{R}^{2}$ & 0.069 & 0.203 & 0.112 & 0.225 & 0.225 & 0.102 & 0.000 \\
\hline & STD-tilt (mm) & \pm 42 & \pm 42 & \pm 27 & \pm 42 & \pm 32 & \pm 37 & \pm 25 \\
\hline \multirow{4}{*}{$\begin{array}{r}(b) \\
\text { Lyon et } \\
\text { al. } \\
(2018 \\
\text { Sect } 4.1) \\
\end{array}$} & STD $(\mathrm{mm})$ & \pm 43 & \pm 44 & \pm 38 & \pm 45 & \pm 39 & \pm 38 & \pm 33 \\
\hline & $\begin{array}{l}\text { Linear tilt } \\
(\mathrm{mm} / \mathrm{km})\end{array}$ & $0.8 \pm 0.6$ & $1.8 \pm 0.5$ & $1.0 \pm 0.5$ & $1.8 \pm 0.5$ & $1.8 \pm 0.5$ & $1.0 \pm 0.5$ & $0.1 \pm 0.4$ \\
\hline & $\mathrm{R}^{2}$ & 0.044 & 0.212 & 0.081 & 0.208 & 0.259 & 0.090 & 0.001 \\
\hline & STD-tilt (mm) & \pm 42 & \pm 40 & \pm 37 & \pm 41 & \pm 35 & \pm 37 & \pm 33 \\
\hline \multirow{4}{*}{$\begin{array}{r}(c) \\
\text { Sept } \\
2017 \\
\text { levelling }\end{array}$} & STD (mm) & \pm 22 & \pm 20 & \pm 27 & \pm 19 & \pm 16 & \pm 17 & \pm 30 \\
\hline & $\begin{array}{l}\text { Linear tilt } \\
(\mathrm{mm} / \mathrm{km})\end{array}$ & $-0.8 \pm 0.2$ & $0.1 \pm 0.2$ & $-0.9 \pm 0.3$ & $0.2 \pm 0.2$ & $0.0 \pm 0.2$ & $-0.6 \pm 0.2$ & $-1.8 \pm 0.3$ \\
\hline & $\mathrm{R}^{2}$ & 0.156 & 0.003 & 0.148 & 0.017 & 0.001 & 0.202 & 0.461 \\
\hline & STD-tilt (mm) & \pm 20 & \pm 20 & \pm 25 & \pm 18 & \pm 16 & \pm 15 & \pm 22 \\
\hline \multirow{4}{*}{$\begin{array}{r}(d) \\
\text { Sept } \\
2017+ \\
\text { linear }\end{array}$} & STD (mm) & \pm 20 & \pm 19 & \pm 27 & \pm 17 & \pm 15 & \pm 16 & \pm 30 \\
\hline & $\begin{array}{l}\text { Linear tilt } \\
(\mathrm{mm} / \mathrm{km})\end{array}$ & $-0.7 \pm 0.2$ & $0.2 \pm 0.2$ & $-0.8 \pm 0.3$ & $0.3 \pm 0.2$ & $0.1 \pm 0.2$ & $-0.6 \pm 0.2$ & $-1.7 \pm 0.3$ \\
\hline & $R^{2}$ & 0.155 & 0.011 & 0.123 & 0.040 & 0.009 & 0.188 & 0.424 \\
\hline & STD-tilt (mm) & \pm 18 & \pm 19 & \pm 26 & \pm 16 & \pm 15 & \pm 14 & \pm 23 \\
\hline \multirow{4}{*}{$\begin{array}{r}(\mathrm{e}) \\
\text { Sept } \\
2017+ \\
\text { linear }+ \\
\text { seasonal }\end{array}$} & STD (mm) & \pm 21 & \pm 19 & \pm 28 & \pm 18 & \pm 16 & \pm 17 & \pm 31 \\
\hline & $\begin{array}{l}\text { Linear tilt } \\
(\mathrm{mm} / \mathrm{km})\end{array}$ & $-0.8 \pm 0.2$ & $0.1 \pm 0.2$ & $-1.0 \pm 0.3$ & $0.2 \pm 0.2$ & $0.0 \pm 0.2$ & $-0.7 \pm 0.2$ & $-1.9 \pm 0.3$ \\
\hline & $\mathrm{R}^{2}$ & 0.179 & 0.001 & 0.152 & 0.014 & 0.000 & 0.224 & 0.457 \\
\hline & STD-tilt (mm) & \pm 19 & \pm 19 & \pm 26 & \pm 18 & \pm 16 & \pm 15 & \pm 23 \\
\hline
\end{tabular}

Table 2: Standard deviations of differences between GPS-levelling and quasigeoid models, linear tilts, coefficients of determination and standard deviations after removal of a linear tilt (STD-tilt) for levelling options a through e as per the caption of Figure 1. Italic text for the lowest standard deviation indicates the "best" quasigeoid model vs GPSlevelling. Bold text indicates whether the tilt is statistically significant at the $95 \%$ confidence level. 


\section{Different GPS processing packages}

We next investigate the effect of using different GPS post-processing packages on the assessment of gravimetric quasigeoid models using GPS-levelling. We only assess the gravimetric quasigeoid models that have not been fitted to GPS-AHD data, which also excludes AUSGeoid98 because this was patch-fitted to GPS-AHD data in the Perth region only (Featherstone, 2000).

Around $50 \%$ of the repeat-levelled benchmarks in the profile used by Lyon et al. (2018) and Schack et al. (2018) are not suitable for geodetic GPS occupation because of obstructions to sky visibility. Eccentric occupations were established at these locations and connected to the benchmarks by differential levelling (third-order) over the short ( $<50 \mathrm{~m}$ ) distances. Each station was occupied by surveyors from the Western Australian geodetic agency, Landgate, for at least six hours with dual-frequency GPS receivers (Leica GS15 with LEIGS15 NONE antenna and Ashtech PM-500 with MAG990596 NONE antenna). Not all were observed simultaneously, so each station had to be processed using free on-line services, but which can give different results (e.g., Ghoddousi-Fard and Dare, 2005; Taskiri, 2008; Jamieson and Gillins, 2018).

The latter is an important consideration when assessing gravimetric quasi/geoid models with GPSlevelling data supplied by others. We attempted to process these third-party-provided GPS data with four on-line services: (i) Geoscience Australia's AUSPOS http://www.ga.gov.au/bin/gps.pl, (ii) Canada's CSRS https://webapp.geod.nrcan.gc.ca/geod/tools-outils/ppp.php, (iii) NASA-JPL's APPS

http://apps.gdgps.net/apps file upload.php, and (iv) Trimble's CenterPoint RTX

https://www.trimblertx.com/. Only AUSPOS and CSRS delivered position solutions for all stations, whereas APPS and RTX either failed to deliver solutions or gave spurious results with very large standard errors. One candidate explanation is incorrect or incomplete information in the RINEX headers, but more likely that the MAG990596 NONE antenna does not have an IGS antex calibration. It appears as though AUSPOS and CSRS use calibrations for this antenna from another source, but this has not yet been confirmed.

Differences in the results from AUSPOS and CSRS are to be expected because they use different processing approaches and some different models (e.g., atmosphere, tides and loading). CSRS uses the precise point positioning technique, which does not use double differencing over baselines, instead using precise satellite orbits and clock parameters (e.g., Zumberg et al., 1997; Kouba and Héroux, 2001). AUSPOS uses double differencing over baselines with respect to continuously operating GPS receivers and the Bernese post-processing software (Dach et al., 2015).

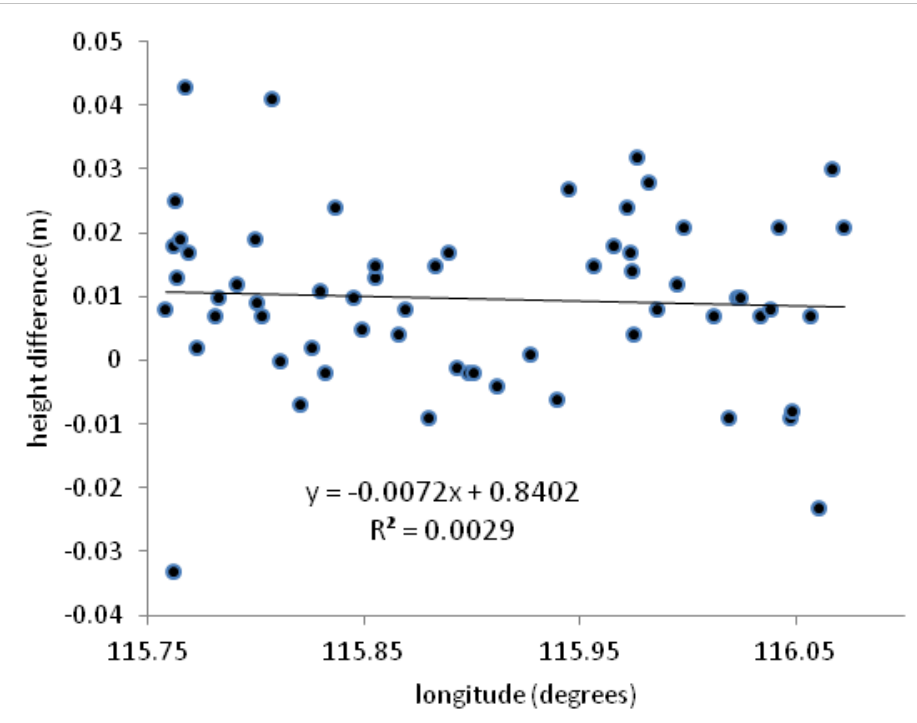

Figure 2: Difference between ITRF2014/GRS80 ellipsoidal heights (metres) from AUSPOS and CSRS as a function of longitude (degrees)

Figure 2 shows the difference between ITRF2014 ellipsoidal heights (with respect to the GRS80 ellipsoid) from AUSPOS and CSRS versus longitude for our EW GPS-levelling traverse. The differences are quite large and attributed to the different techniques, software, processing parameters and models used by AUSPOS and CSRS. The ellipsoidal height difference between the Australian GDA94 and GDA2020 
https://ascelibrary.org/doi/10.1061/\%28ASCE\%29SU.1943-5428.0000293

datums is a near-constant $0.080 \mathrm{~m}$ (not plotted here), which is due to the different realisations of ITRF in each (ITRF92 epoch 1994.0 for GDA94 and ITRF2014 epoch 2020.0 for GDA2020). Recall, however, the discussion in Section 2 on disregarding the mean when assessing quasi/geoid models using GPS-levelling.

The difference in ellipsoidal heights from AUSPOS and CSRS is sometimes larger than their formally reported errors. For the 62 stations used in this study and for ITRF2014, the mean of the height error reported by AUSPOS is $17 \mathrm{~mm}$ ( $\max 25 \mathrm{~mm}$ ) and for CSRS is $23 \mathrm{~mm}$ ( $\max 47 \mathrm{~mm}$ ). There is also a bias of $\sim 10 \mathrm{~mm}$ between them (Figure 2), but again this is of lesser concern for assessing gravimetric quasi/geoid models with GPS-levelling because we do not use the mean. The tilt of $7 \mathrm{~mm} /$ degree (Figure 2) equates to $0.06 \mathrm{~mm} / \mathrm{km}$, which cannot explain the $\sim 1 \mathrm{~mm} / \mathrm{km}$ reported by Schack et al. (2018).

\begin{tabular}{|c|c|c|c|c|c|c|c|c|c|}
\hline & & EGM2008 & GGMplus & AGQG2009 & AGQG2017 & EGM2008 & GGMplus & AGQG2009 & AGQG2017 \\
\hline & $\begin{array}{r}\text { Processing } \\
\text { software }\end{array}$ & \multicolumn{4}{|c|}{ AUSPOS } & \multicolumn{4}{|c|}{ CSRS } \\
\hline \multirow{4}{*}{$\begin{array}{r}(\mathrm{a}) \\
\text { "official" AHD } \\
1971\end{array}$} & STD (mm) & \pm 44 & \pm 47 & \pm 48 & \pm 39 & \pm 44 & \pm 48 & \pm 48 & \pm 40 \\
\hline & $\begin{array}{l}\text { Linear tilt } \\
(\mathrm{mm} / \mathrm{km})\end{array}$ & $1.0 \pm 0.5$ & $1.9 \pm 0.5$ & $2.0 \pm 0.5$ & $1.1 \pm 0.4$ & $1.0 \pm 0.5$ & $1.8 \pm 0.5$ & $1.9 \pm 0.5$ & $1.0 \pm 0.4$ \\
\hline & $\mathrm{R}^{2}$ & 0.069 & 0.203 & 0.224 & 0.101 & 0.069 & 0.186 & 0.210 & 0.088 \\
\hline & STD-tilt $(\mathrm{mm})$ & \pm 42 & \pm 42 & \pm 42 & \pm 37 & \pm 42 & \pm 43 & \pm 43 & \pm 38 \\
\hline \multirow{4}{*}{$\begin{array}{r}\text { (b) } \\
\text { Lyon et al. } \\
(2018, \text { Sect } \\
4.1)\end{array}$} & STD (mm) & \pm 43 & \pm 44 & \pm 45 & \pm 38 & \pm 43 & \pm 44 & \pm 44 & \pm 38 \\
\hline & $\begin{array}{l}\text { Linear tilt } \\
(\mathrm{mm} / \mathrm{km})\end{array}$ & $0.7 \pm 0.6$ & $1.7 \pm 0.6$ & $1.7 \pm 0.6$ & $0.9 \pm 0.5$ & $0.7 \pm 0.6$ & $1.6 \pm 0.6$ & $1.6 \pm 0.6$ & $0.8 \pm 0.5$ \\
\hline & $\mathrm{R}^{2}$ & 0.029 & 0.178 & 0.176 & 0.067 & 0.029 & 0.165 & 0.169 & 0.059 \\
\hline & STD-tilt (mm) & \pm 42 & \pm 40 & \pm 41 & \pm 37 & \pm 42 & \pm 40 & \pm 40 & \pm 37 \\
\hline \multirow{5}{*}{$\begin{array}{r}\text { (c) } \\
\text { Sept } 2017 \\
\text { levelling }\end{array}$} & & & & & & & & & \\
\hline & STD (mm) & \pm 22 & \pm 20 & \pm 19 & \pm 17 & \pm 22 & \pm 23 & \pm 21 & \pm 20 \\
\hline & $\begin{array}{l}\text { Linear tilt } \\
(\mathrm{mm} / \mathrm{km})\end{array}$ & $-0.8 \pm 0.2$ & $0.1 \pm 0.2$ & $0.2 \pm 0.2$ & $-0.7 \pm 0.2$ & $-0.8 \pm 0.2$ & $0.0 \pm 0.3$ & $0.1 \pm 0.2$ & $-0.8 \pm 0.2$ \\
\hline & $R^{2}$ & 0.157 & 0.003 & 0.017 & 0.204 & 0.157 & 0.000 & 0.007 & 0.178 \\
\hline & STD-tilt $(\mathrm{mm})$ & \pm 20 & \pm 20 & \pm 18 & \pm 15 & \pm 20 & \pm 23 & \pm 20 & \pm 18 \\
\hline & & & & & & & & & \\
\hline \multirow{4}{*}{$\begin{array}{r}(d) \\
\text { Sept } 2017+ \\
\text { linear }\end{array}$} & STD $(\mathrm{mm})$ & \pm 20 & \pm 19 & \pm 17 & \pm 16 & \pm 20 & \pm 23 & \pm 20 & \pm 20 \\
\hline & $\begin{array}{l}\text { Linear tilt } \\
(\mathrm{mm} / \mathrm{km})\end{array}$ & $-0.7 \pm 0.2$ & $0.2 \pm 0.2$ & $0.3 \pm 0.2$ & $-0.6 \pm 0.2$ & $-0.7 \pm 0.2$ & $0.1 \pm 0.3$ & $0.2 \pm 0.2$ & $-0.7 \pm 0.2$ \\
\hline & $R^{2}$ & 0.157 & 0.010 & 0.039 & 0.190 & 0.157 & 0.003 & 0.017 & 0.143 \\
\hline & STD-tilt (mm) & \pm 18 & \pm 19 & \pm 16 & \pm 14 & \pm 18 & \pm 23 & \pm 20 & \pm 19 \\
\hline \multirow{4}{*}{$\begin{array}{r}(e) \\
\text { Sept } 2017+ \\
\text { linear + } \\
\text { seasonal }\end{array}$} & STD $(\mathrm{mm})$ & \pm 21 & \pm 19 & \pm 18 & \pm 17 & \pm 21 & \pm 22 & \pm 20 & \pm 20 \\
\hline & $\begin{array}{l}\text { Linear tilt } \\
(\mathrm{mm} / \mathrm{km})\end{array}$ & $-0.8 \pm 0.2$ & $0.1 \pm 0.2$ & $0.2 \pm 0.2$ & $-0.7 \pm 0.2$ & $-0.8 \pm 0.2$ & $0.0 \pm 0.3$ & $0.1 \pm 0.2$ & $-0.8 \pm 0.2$ \\
\hline & $\mathrm{R}^{2}$ & 0.181 & 0.001 & 0.013 & 0.225 & 0.181 & 0.000 & 0.004 & 0.189 \\
\hline & STD-tilt (mm) & \pm 19 & \pm 19 & \pm 18 & \pm 15 & \pm 19 & \pm 22 & \pm 20 & \pm 18 \\
\hline
\end{tabular}

Table 3: Standard deviations of differences between GPS-levelling and gravimetric-only quasigeoid models, linear tilts, coefficients of determination and standard deviations after removal of the linear tilt (STD-tilt) for levelling options a through e as per the caption of Figure 1. Slightly different results arise from the use of different GPS processing packages, but the conclusions inferred are essentially the same as from Table 2 . Italic text for the standard deviation indicates the "best" quasigeoid model vs GPS-levelling. Red text indicates whether the tilt is statistically significant at the $95 \%$ confidence level.

The recommendations from these experiments, which apply elsewhere and not only to GPS-levelling assessments of gravimetric quasigeoid models, are: (i) GPS/GNSS antennas should be used that have IGS antex calibrations; (ii) RINEX headers should be scrutinised to ensure they contain all of the information required for any automated processing; (iii) a consistent ITRF reference frame should be used; (iv) a 
consistent processing package should be used so as to avoid the potential for centimetric differences (cf. Figure 2), particularly in the modern quest for a centimetric quasi/geoid (e.g., Sansò and Rummel, 1997; Brockman et al., 2014; Foroughi et al., 2018). Regarding the reference frame in GPS processing, the ITRF has had many manifestations over time, with the latest being ITRF2014 (Altamimi et al., 2016). This affects legacy GPS data processed in an earlier realisation. These need to be reprocessed in the latest frame because when a new realisation is released, legacy frames are no longer supported by the producers of precise orbits and satellite clocks.

Table 3 repeats the analysis from the previous subsection, but now using ITRF2014 ellipsoidal heights from AUSPOS and CSRS. The conclusions reached from Table 3 are the same as those reached from Table 2 , but the recommendations above must be kept in mind when assessing quasigeoid models using GPSlevelling.

\section{Concluding remarks}

We exemplify that choosing the "best" gravimetric quasi/geoid model from GPS-levelling data is not so straightforward, as also alluded to in Featherstone et al. (2018). Though this study is small (a $40 \mathrm{~km}$-long EW traverse in Perth, Western Australia, using 62 GPS-levelling points), the effects of vertical land motion can obscure this choice. Schack et al. (2018) attributed their observed $\sim 1 \mathrm{~mm} / \mathrm{km}$ tilt in the quasigeoid to the poor quality of the altimeter data and steep gravity gradients in Perth, but vertical land motion may also be a candidate. As such, the question of assessing the origin of tilts in gravimetric quasi/geoid models from GPS-levelling data appears to remain somewhat open.

Data Availability Statement: Some or all data, models, or code used during the study were provided by a third party. (GPS RINEX data from Irek Baran at Landgate, GGMplus from Christian Hirt at Technical University of Munich). Direct requests for these materials may be made to the provider as indicated in the Acknowledgments. Some or all data, models, or code generated or used during the study are available from the corresponding author by request. (levelling data)

Acknowledgements: We thank Irek Baran, Rod Stone and Kent Wheeler from the Western Australian geodetic agency, Landgate, for collecting and providing the GPS data, and Christian Hirt from the Technical University of Munich for providing GGMplus values. Thanks also go to the anonymous reviewers and editors for their time and effort. Jack McCubbine publishes this paper with the permission of the Chief Executive Officer of Geoscience Australia.

\section{References}

Allister, N.A. and W.E. Featherstone (2001) Estimation of Helmert orthometric heights using digital barcode levelling, observed gravity and topographic mass-density data over part of the Darling Scarp, Western Australia, Geomatics Research Australasia 75: 25-52.

Altamimi, Z., P. Rebischung, L. Métivier and C. Xavier (2016) ITRF2014: A new release of the International Terrestrial Reference Frame modelling nonlinear station motions, Journal of Geophysical Research Solid Earth 121(8), 6109-6131, https://doi.org/10.1002/2016JB013098.

Andersen, O.B., P. Knudsen and P.A.M. Berry (2010) The DNSC08GRA global marine gravity field from double retracked satellite altimetry, Journal of Geodesy 84(3): 191-199, https://doi.org/10.1007/s00190-009-0355-9.

Brockmann, J.M., N. Zehentner, E. Höck, R. Pail, I. Loth, T. Mayer-Gürr and W-D. Schuh (2014) EGM_TIM_RL05: An independent geoid with centimeter accuracy purely based on the GOCE mission, Geophysical Research Letters 41(22): 8089-8099, https://doi.org/10.1002/2014GL061904.

Brown, N.J., J.C. McCubbine, W.E. Featherstone, A. Woods, I. Baran and N. Gowans (2018) AUSGeoid2020 combined gravimetric-geometric model with location-specific uncertainties and baseline-lengthdependent error decorrelation, Journal of Geodesy 92(12): 1457-1465, https://doi.org/10.1007/s00190-018-1202-7. 
https://ascelibrary.org/doi/10.1061/\%28ASCE\%29SU.1943-5428.0000293

Brown, N.J., W.E. Featherstone, G. Hu and G.M. Johnston (2011) AUSGeoid09: a more direct and more accurate model for converting ellipsoidal heights to AHD heights, Journal of Spatial Science 56(1): 27-37, https://doi.org/10.1080/14498596.2011.580498.

Claessens, S.J., W.E. Featherstone and F. Barthelmes (2001) Experiences with point-mass gravity field modelling in the Perth region, Western Australia, Geomatics Research Australasia 75: 53-86.

Dach, R., S. Lutz, P. Walser and P. Fridez (2015) Bernese GNSS software version 5.2, Astronomical Institute, University of Bern, Switzerland, http://www.bernese.unibe.ch/docs/DOCU52.pdf.

Darbeheshti, N. and W.E. Featherstone (2010) Tuning a gravimetric quasigeoid to GPS-levelling by nonstationary least-squares collocation, Journal of Geodesy 84(7): 419-431, https://doi.org/10.1007/s00190-010-0377-3.

Dawson, J. and A. Woods (2010) ITRF to GDA94 coordinate transformations, Journal of Applied Geodesy 4 (2010): 189-199, https://doi.org/10.1515/JAG.2010.019.

Ekman, M. (1989) Impacts of geodynamic phenomena on systems for height and gravity, Bulletin Géodésique 63(3): 281-296, https://doi.org/10.1007/BF02520477.

Farr, T.G., Rosen PA, Caro E, Crippen R, Duren R, Hensley S, Kobrick M, Paller M, Rodriguez E, Roth L, Seal D, Shaffer S, Shimada J, Umland J, Werner M, Oskin M, Burbank D, Alsdorf D (2007) The Shuttle Radar Topography Mission, Reviews of Geophysics 45(2): RG2004, https://doi.org/10.1029/2005RG000183.

Featherstone, W.E. (1998) Do we need a gravimetric geoid or a model of the base of the Australian Height Datum to transform GPS heights? The Australian Surveyor 43(4): 273-280.

https://doi.org/10.1080/00050350.1998.10558758.

Featherstone, W.E. (2000) Refinement of gravimetric geoid using GPS and levelling data, Journal of Surveying Engineering 126(2): 27-56, https://doi.org/10.1061/(ASCE)0733-9453(2000)126:2(27).

Featherstone, W.E. (2008) GNSS-based heighting in Australia: current, emerging and future issues, Journal of Spatial Science 53(2): 115-133, https://doi.org/10.1080/14498596.2008.9635153.

Featherstone, W.E. (2009) Only use ship-track gravity data with caution: a case-study around Australia, Australian Journal of Earth Sciences 56(2): 191-195, https://doi.org/10.1080/08120090802547025.

Featherstone, W.E. and D.M. Sproule (2006) Fitting AUSGeoid98 to the Australian Height Datum using GPS data and least squares collocation: application of a cross-validation technique, Survey Review 38(301): 573-582, https://doi.org/10.1179/003962606780732065.

Featherstone, W.E. and M. Kuhn (2006) Height systems and vertical datums: a review in the Australian context, Journal of Spatial Science 51(1): 21-42, https://doi.org/10.1080/14498596.2006.9635062.

Featherstone, W.E. and M.S. Filmer (2012) The north-south tilt in the Australian Height Datum is explained by the ocean's mean dynamic topography, Journal of Geophysical Research - Oceans 117(C8), C08035, https://doi.org/10.1029/2012JC007974.

Featherstone, W.E., J.C. McCubbine, N.J. Brown, S.J. Claessens, M.S. Filmer, and J.F. Kirby (2018) The first Australian gravimetric quasigeoid model with location-specific uncertainty estimates, Journal of Geodesy 92(2): 149-168, https://doi.org/10.1007/s00190-017-1053-7.

Featherstone, W.E., J.F. Kirby, A.H.W. Kearsley, J.R. Gilliland, G.M. Johnston, J. Steed, R. Forsberg and M.G. Sideris (2001) The AUSGeoid98 geoid model of Australia: data treatment, computations and comparisons with GPS-levelling data, Journal of Geodesy 75(5-6): 313-330, https://doi.org/10.1007/s001900100177.

Featherstone, W.E., J.F. Kirby, C. Hirt, M.S. Filmer, S.J. Claessens, N.J. Brown, G. Hu and G.M. Johnston (2011) The AUSGeoid09 model of the Australian Height Datum, Journal of Geodesy 85(3): 133-150, https://doi.org/10.1007/s00190-010-0422-2.

Featherstone, W.E., N.T. Penna, M.S. Filmer and S.D.P. Williams (2015) Nonlinear subsidence at Fremantle, a long-recording tide gauge in the Southern Hemisphere, Journal of Geophysical Research - Oceans 120(10): 7004-7014, https://doi.org/10.1002/2015JC011295.

Filmer, M.S., C.W. Hughes, P.L. Woodworth, W.E. Featherstone and R.J. Bingham (2018) Comparison between geodetic and oceanographic approaches to estimate mean dynamic topography for vertical datum unification: evaluation at Australian tide gauges, Journal of Geodesy 92(12): 1413-1437, https://doi.org/10.1007/s00190-018-1131-5. 
https://ascelibrary.org/doi/10.1061/\%28ASCE\%29SU.1943-5428.0000293

Foroughi, I., P. Vaníček, R.W. Kingdon, M. Goli, M. Sheng, Y. Afrasteh, P. Novák and M.C. Santos (2018) Subcentimetre geoid, Journal of Geodesy, https://doi.org/10.1007/s00190-018-1208-1.

Friedlieb, O.J., W.E. Featherstone and M.C. Dentith (1997) A WGS84-AHD profile over the Darling Fault, Western Australia, Geomatics Research Australasia 67: 17-32. [Publisher's erratum in Geomatics Research Australasia 68]

Gallant, J.C., T.I. Dowling, A.M. Read, N. Wilson, P. Tickle and C. Inskeep (2011) 1 second SRTM Derived Digital Elevation Models User Guide, Geoscience Australia, Canberra www.ga.gov.au/topographicmapping/digital-elevation-data.html

Ghoddousi-Fard, R. and P. Dare (2005) Online GPS processing services: an initial study, GPS Solutions 10(1): 12-20, https://doi.org/10.1007/s10291-005-0147-5.

Hirt, C., S.J. Claessens, T. Fecher, M. Kuhn, R. Pail and M. Rexer (2013) New ultrahigh-resolution picture of Earth's gravity field, Geophysical Research Letters 40(16): 4279-4283, https://doi.org/10.1002/grl.50838.

Jamieson, M. and D.T. Gillins (2018) Comparative analysis of online static GNSS post-processing services, Journal of Surveying Engineering 144(4), https://doi.org/10.1061/(ASCE)SU.1943-5428.0000256.

Kirby, J.F. and W.E. Featherstone (2001) Anomalously large gradients in the "GEODATA 9 SECOND" Digital Elevation Model of Australia, and their effects on gravimetric terrain corrections, Cartography 30(1): 110.

Kotsakis, C. (2008) Transforming ellipsoidal heights and geoid undulations between different geodetic reference frames, Journal of Geodesy 82(4-5): 249-260, https://doi.org/10.1007/s00190-007-0174-9.

Kotsakis, C. (2009) A study on the reference frame consistency in recent Earth gravitational models. Journal of Geodesy 83:31. https://doi.org/10.1007/s00190-008-0227-8.

Kouba, J. and P. Héroux (2001) Precise point positioning using IGS orbit and clock products, GPS Solutions 5(2): 12-28, https://doi.org/10.1007/PL00012883.

Lines, J.D. (1992) Australia on paper: The story of Australian mapping, Fortune Publications, $343 \mathrm{pp}$.

Lyon, T.J., M.S. Filmer and W.E. Featherstone (2018) On the use of repeat leveling for the determination of vertical land motion: artifacts, aliasing and extrapolation, Journal of Geophysical Research - Solid Earth 123(8): 7021-7039. https://doi.org/10.1029/2018JB015705.

Middleton MF, Wilde SA, Evans BA, Long A and Dentith MC (1993) A preliminary interpretation of deep seismic reflection and other geophysical data from the Darling Fault zone, Western Australia.

Exploration Geophysics 24(3-4): 711-718. https://doi.org/10.1071/EG993711.

Moritz H (2000) Geodetic Reference System 1980. Journal of Geodesy 74(1): 128-140. https://doi.org/10.1007/s001900050278.

Parker, A.L., M.S. Filmer and W.E. Featherstone (2017a) First results from Sentinel-1A InSAR over Australia: Application to the Perth Basin, Remote Sensing 9(3), 299, https://doi.org/10.3390/rs9030299.

Parker, A.L., W.E. Featherstone, N.T. Penna, M.S. Filmer and M.C. Garthwaite (2017b) Practical considerations before installing ground-based geodetic infrastructure for integrated InSAR and cGNSS monitoring of vertical land motion, Sensors 17(8), 1753, https://doi.org/10.3390/s17081753.

Pavlis N.K., S.A. Holmes, S.C. Kenyon and J.K. Factor (2012) The development and evaluation of the Earth Gravitational Model 2008 (EGM2008), Journal of Geophysical Research - Solid Earth, 117(B4), B04406. https://doi.org/10.1029/2011JB008916.

Pavlis N.K., S.A. Holmes, S.C. Kenyon and J.K. Factor (2013) Correction to "The development and evaluation of the Earth Gravitational Model 2008 (EGM2008)", Journal of Geophysical Research - Solid Earth, 118(B5), 2633. https://doi.org/10.1002/igrb.50167.

Pavlis, E.C. (1998) On the reference frames inherent in recent geopotential models. In: Vermeer M, Adam J (eds) Proceedings of the Second Continental Workshop on the Geoid in Europe, Budapest, Hungary 1014, March 1998. Reports of the Finnish Geodetic Institute, Massala 98(4): 29-40.

Penna, N.T., W.E. Featherstone, J. Gazeaux and R.J. Bingham (2013) The apparent British sea slope is caused by systematic errors in the levelling-based vertical datum, Geophysical Journal International 194(2): 772-786, https://doi.org/10.1093/gji/ggt161. 
Saleh, J. and N.K. Pavlis (2003) The development and evaluation of the global digital terrain model DTM2002, Gravity and Geoid 2002: Proceedings of the Third Meeting of the IGGC, pp. 207-212, Ziti, Thessaloniki, Greece.

Sandwell, D.T., R.D. Müller, W.H.F Smith, E. Garcia and R. Francis (2014) New global marine gravity model from CryoSat-2 and Jason-1 reveals buried tectonic structure, Science 346(6205): 65-67, https://doi.org/10.1126/science.1258213.

Sansò, F. and R. Rummel (1997) Geodetic Boundary Value Problems in View of the One Centimeter Geoid, Lecture Notes in Earth Sciences 65, Springer, Heidelberg.

Schack, P., C. Hirt, M. Hauk, W.E. Featherstone, T.J. Lyon and S. Guillaume (2018) A high-precision digital astrogeodetic traverse in an area of steep geoid gradients and close to the coast of Perth, Western Australia, Journal of Geodesy 92(10): 1143-1153, https://doi.org/10.1007/s00190-017-1107-x.

Smith, D.A. (1998) There is no such thing as "The" EGM96 geoid: Subtle points on the use of a global geopotential model, International Geoid Service Bulletin 8: 17-28. https://www.ngs.noaa.gov/PUBS LIB/EGM96 GEOID PAPER/egm96 geoid paper.html

Tsakiri, M. (2008) GPS processing using online services, Journal of Surveying Engineering 134(4): 115-125, https://doi.org/10.1061/(ASCE)0733-9453(2008)134:4(115).

Vatrt, V. (1999) Methodology of testing geopotential models specified in different tide system, Studia Geophysica et Geodaetica 43(1): 73-77, https://doi.org/10.1023/A:1023362109108.

Vignudelli ,S., A. Kostianoy, P. Cipollini and J. Benveniste (eds) (2011) Coastal altimetry, Springer, Berlin, 566pp. https://doi.org/10.1007/978-3-642-12796-0.

Wessel, P. and W.H.F. Smith (1996) A global, self-consistent, hierarchical, high-resolution shoreline database, Journal of Geophysical Research - Solid Earth 101(B4): 8741-8743, https://doi.org/10.1029/96JB00104.

Wessel, P., W.H.F. Smith, R. Scharroo, J.F. Luis and F. Wobbe (2013) Generic Mapping Tools: Improved version released, EOS - Transactions of the AGU 94(45): 409-410, https://doi.org/10.1002/2013EO450001.

Zilkoski D., J. Richards and G. Young (1992) Results of the general adjustment of the North American Vertical Datum of 1988, Surveying and Land Information Systems 52(3): 133-149.

Zumberge, J.F., M.B. Heflin, D.C. Jefferson, M.M. Watkins and F.H. Webb (1997) Precise point positioning for the efficient and robust analysis of GPS data from large networks, Journal of Geophysical Research Solid Earth 102(B3): 5005-5017, https://doi.org/10.1029/96JB03860. 